\title{
Study on Histopathology of Ovarian Tumor in Tertiary Hospital
}

\author{
Dr. Hetvi Parikh ${ }^{1}$, Dr. Hansa Goswami², Dr. Urvi Parikh ${ }^{3}$ \\ MBBS, $3^{\text {rd }}$ Year Resident, Department of Pathology, B.J Medical Collage and Civil hospital, Asarwa, Ahmedabad- 380016, Gujarat, India \\ hetvikparikh@gmail.com
}

\begin{abstract}
MBBS, Professor \& Head of the Department, MD Pathology, B.J Medical Collage and Civil hospital, Asarwa, Ahmedabad- 380016 , Gujarat, India

drhansaganatra@yahoo.co.in

MBBS, MD Pathology, Assistant Professor, Department of Pathology, B.J Medical Collage and Civil hospital, Asarwa, Ahmedabad- 380016, Gujarat, India

urviparikh76@gmail.com
\end{abstract}

\begin{abstract}
Background: Ovaries are common site for both benign and malignant neoplasm in all age groups right from intrauterine period to post menopausal age group. Neoplastic disorders or lesions of ovary can arise from Mullerian epithelium, Germ cells or Sex cord Stromal cells. A Total of 100 cases of diagnosed ovarian tumors are included in the study. We have included parameters like Age wise incidence, Nature of Lesion, Frequency \& Laterality in this study. Results: Out of 100 cases, 93\% cases were unilateral and $7 \%$ cases were bilateral. Majority of cases (48\%) belong to age group of 20-39 year. $91 \%$ cases were benign, $1 \%$ case was borderline and $8 \%$ were malignant. In benign ovarian neoplasm, serous cystadenoma was the most common followed by mature cystic teratoma and mucinous cystadenoma. In malignant cases, maximum cases were of serous cystadenocarcinoma. Conclusion: Ovarian tumors include a variety of morphological features and show predominance in particular age group. Role of histopathological evaluation remains always important in both diagnosis and management of such cases, particularly in cases of Malignant Lesions in order to save the patient's life.
\end{abstract}

Keywords: Benign, Surface epithelial tumors, Serous cystadenoma

\section{Introduction}

The ovary consists of totipotent sex cells and multipotent mesenchymal cells ${ }^{[1]}$. Ovaries are common site for both benign and malignant neoplasm in all age groups right from intrauterine period to post menopausal age group ${ }^{[2]}$. Almost $80 \%$ of the ovarian neoplasms are benign. It is also a common site for primary malignancy, although metastasis to ovaries can also occur ${ }^{[3]}$. Ovarian tumors are leading cause of death from gynecological malignancy. ${ }^{[4][5]}$

Neoplastic lesions of ovary can arise from Mullerian epithelium, Germ cells or Sex cord Stromal cells ${ }^{[6]}$. They are further categorized into benign, borderline and malignant [7][8]

Ovarian neoplasm behave in diverse way and generally escape the detection until they attain a larger size. Therefore, diagnosis of various histological patterns of ovarian tumors is very important in the treatment and prognosis ${ }^{[8][9]}$.

\section{Aims and Objectives}

1) To study the histopathological patterns of ovarian tumors.

2) To study age wise incidence of ovarian tumors.

3) To study the frequency of ovarian tumors in terms of benign, borderline or malignant

4) To study laterality of ovarian tumors

\section{Material and Method}

The present study was carried out in the Department of Pathology, tertiary care teaching hospital, Ahmedabad over a period of three years from January 2018 to December 2020. Cases of ovarian masses which underwent oophorectomy or hysterectomy with bilateral/ unilateral salpingo-oophorectomy were sent for histopathological examination. Information regarding the age, clinical history and clinical diagnosis were obtained. All specimens were processed by routine histopathological procedure followed by $\mathrm{H} \& \mathrm{E}$ staining. Then microscopic examination was done and results were analysed.

\section{Result}

The present study included 100 cases of ovarian tumors. The histopathological categorization was done according to the site of origin: Surface epithelial tumors, germ cell tumors, sex cord stromal tumors and metastatic tumors. They were further divided into Benign, Borderline and Malignant tumors.

In present study 91 cases were Benign (91\%), 1 was Borderline $(1 \%)$ and 8 were Malignant $(8 \%)$. Unilateral tumors $(93 \%)$ were more common than bilateral tumors $(8 \%)$.

The most common tumor of ovary was Benign serous cystadenoma (38\%) followed by Mature cystic teratoma (22\%), followed by Benign mucinous cystadenoma (20\%). (Table I) 
Among the Benign tumors (91\%), 3\% cases of Serous cystadenoma were bilateral while $1 \%$ case of Mucinous cystadenoma and $2 \%$ cases of Mature cystic terartomas were bilateral. While among the malignant tumors (7\%), $1 \%$ case was bilateral which was Papillary Serous cystadenocarcinoma.
Patients in age group of 20-39 years constituted the majority of patients $(50 \%)$, followed by the age group of 40-59 years (23\%). (Table II) Our youngest patient was 3 months old child while the oldest patient was 82 years old female.

Histopathological categorization of various ovarian tumors are given in Table I and their age wise distribution is given in Table II.

Table I: Histopathological categorization of various Ovarian tumors

\begin{tabular}{|c|c|c|c|c|c|}
\hline Site of origin & Benign/Borderline/malignant & Histopatological Category & Unilateral & Bilateral & Total \\
\hline \multirow{9}{*}{ Surface Epithelial Tumor } & \multirow{6}{*}{ Benign } & Serous cystadenoma & 35 & 3 & 38 \\
\hline & & Mucinous cystadenoma & 17 & 1 & 18 \\
\hline & & Serous cystadenofibroma & 7 & - & 7 \\
\hline & & Seromucinous cystadenoma & 1 & - & 1 \\
\hline & & Brenner tumor & 2 & - & 2 \\
\hline & & Endometroid tumor & 1 & - & 1 \\
\hline & Borderline & Mucinous tumor & 1 & - & 1 \\
\hline & \multirow{2}{*}{ Malignant } & High grade serous carcinoma & 1 & - & 1 \\
\hline & & Papillary serous cystadenocarcinoma & - & 1 & 1 \\
\hline \multirow{3}{*}{ Germ cell tumor } & Benign & Mature cystic teratoma (Dermoid cyst) & 20 & 2 & 22 \\
\hline & \multirow{2}{*}{ Malignant } & Immature teratoma & 2 & - & 2 \\
\hline & & Yolk sac tumor & 2 & - & 2 \\
\hline \multirow{2}{*}{ Sex cord Stromal tumor } & Benign & Fibrothecoma & 2 & - & 2 \\
\hline & Malignant & Adult granulosa cell tumor & 1 & - & 1 \\
\hline Metastatic tumor & Malignant & Metastatic adenocarcinoma & 1 & - & 1 \\
\hline
\end{tabular}

Table II: Age wise distribution of various Ovarian tumors

\begin{tabular}{|c|c|c|c|c|}
\hline Category & $\begin{array}{c}\leq 19 \\
\text { years }\end{array}$ & $\begin{array}{c}20-39 \\
\text { years }\end{array}$ & $\begin{array}{c}40-59 \\
\text { years }\end{array}$ & $\begin{array}{c}\geq 60 \\
\text { years }\end{array}$ \\
\hline Benign serous cystadenoma & 4 & 16 & 12 & 6 \\
\hline Benign mucinous cystadenoma & - & 11 & 6 & 3 \\
\hline Benign serous cystadenofibroma & 2 & 3 & - & - \\
\hline Benign seromucinous tumor & - & - & 1 & - \\
\hline Benign Brenner tumor & - & - & 2 & - \\
\hline Benign Endometroid tumor & - & 1 & - & - \\
\hline Borderline mucinous tumor & - & - & 1 & - \\
\hline High grade serous carcinoma & - & - & 1 & - \\
\hline Papillary Serous cystadenocarcinoma & - & - & 1 & - \\
\hline Mature teratoma & 4 & 13 & 5 & - \\
\hline Immature teratoma & 1 & 1 & - & - \\
\hline Malignant yolk sac tumor & 1 & 1 & - & - \\
\hline Fibrothecoma & - & 1 & - & 1 \\
\hline Adult Granulosa cell tumor & - & - & - & 1 \\
\hline Metastatic Adenocarcinoma & - & 1 & - & - \\
\hline Total & 12 & 48 & 28 & 12 \\
\hline
\end{tabular}

\section{Discussion}

Ovarian cancer is the second leading cause of mortality among all gynecological cancers ${ }^{[11]}$. The structure of the ovary includes germ cells, follicular cells and the ovarian stroma. The function of the ovary is as complex as its structure. Any of these structures can give rise to a plethora of tumors. ${ }^{[10]}$ The determination of these patterns is important for diagnosis, management and prognosis.

Laterality of ovarian neoplastic lesions in various studies in comparison with present study is illustrated in Table III. Majority of the cases are unilateral in Prakash et al., Maru A et al., Misra et al. and Couto F et al. study which are comparable to the present study.
Table III: Laterality of ovarian tumors in various studies in comparison to present study

\begin{tabular}{|l|l|l|}
\hline Author & \multicolumn{2}{|l|}{ Laterality(percentage) } \\
\hline & Unilateral & Bilateral \\
\hline Prakash et al. (2017) [12] & $90.8 \%$ & $9.2 \%$ \\
\hline Maru A et al. (2019) [13] & $89 \%$ & $11 \%$ \\
\hline Misra et al. (1990) [14] & $95.5 \%$ & $4.5 \%$ \\
\hline Couto F et al. (1993) [15] & $91.2 \%$ & $8.7 \%$ \\
\hline Present study & $93 \%$ & $7 \%$ \\
\hline
\end{tabular}

The percentage distribution of patients in various age groups in comparison with other studies is illustrated in Table IV. In Prakash et al., Pilli et al., and Ramchandra et al. study the most common age of presentation is 20-39 years followed by $40-59$ years. This is comparable to our present study.

Table IV: Percentage distribution of cases in various age groups in comparison with present study

\begin{tabular}{|c|c|c|c|c|}
\hline Author & $\begin{array}{c}\leq 19 \\
\text { years }\end{array}$ & $\begin{array}{c}20-39 \\
\text { years }\end{array}$ & $\begin{array}{c}40-59 \\
\text { years }\end{array}$ & $\begin{array}{c}\geq 60 \\
\text { years }\end{array}$ \\
\hline Prakash et al. (2017) [12] & $5.7 \%$ & $53.4 \%$ & $36.6 \%$ & $4.3 \%$ \\
\hline Pilli et al. (2002) [16] & $7 \%$ & $58 \%$ & $30 \%$ & $5 \%$ \\
\hline Ramchandra et al. (1972) [22] & $7.9 \%$ & $53 \%$ & $30 \%$ & $9.1 \%$ \\
\hline Present study & $12 \%$ & $48 \%$ & $28 \%$ & $12 \%$ \\
\hline
\end{tabular}

Comparative incidence of neoplastic lesions of ovary according to site of origin shows that the most common site of origin is surface epithelium 
Table V: Comparative incidence of neoplastic lesions of ovary according to site of origin

\begin{tabular}{|c|c|c|c|c|}
\hline Author & $\begin{array}{c}\text { Surface } \\
\text { Epithelial } \\
\text { Tumor }\end{array}$ & $\begin{array}{c}\text { Germ cell } \\
\text { tumor }\end{array}$ & $\begin{array}{c}\text { Sex cord } \\
\text { Stromal } \\
\text { tumor }\end{array}$ & $\begin{array}{c}\text { Metastatic } \\
\text { tumor }\end{array}$ \\
\hline $\begin{array}{c}\text { Maru A et al. (2019) } \\
\text { [13] }\end{array}$ & $73.33 \%$ & $23.33 \%$ & $3.33 \%$ & - \\
\hline Pilli et al. (2002) [16] & $70.9 \%$ & $21.2 \%$ & $6.7 \%$ & $0.7 \%$ \\
\hline $\begin{array}{c}\text { Bhuvanesh et } \\
\text { al.(1978) [21] }\end{array}$ & $78.57 \%$ & $10.85 \%$ & $7.14 \%$ & $1.42 \%$ \\
\hline Gupta et al (2007)[18] & $65.6 \%$ & $23.9 \%$ & $8.3 \%$ & $2 \%$ \\
\hline Present study & $70 \%$ & $26 \%$ & $3 \%$ & $1 \%$ \\
\hline
\end{tabular}

Comparative incidence of most common benign neoplastic lesions of ovary were illustrated in Table VI. This comparision shows that majority of benign tumors are serous cystadenoma.

Table VI: Comparative incidence of most common benign neoplastic lesions of ovary

\begin{tabular}{|c|c|c|c|}
\hline Author & $\begin{array}{c}\text { Serous } \\
\text { cystadenoma }\end{array}$ & $\begin{array}{c}\text { Mature } \\
\text { teratoma }\end{array}$ & $\begin{array}{c}\text { Mucinous } \\
\text { cystadenoma }\end{array}$ \\
\hline Maru A et al. (2019) [13] & $28 \%$ & $13 \%$ & $6 \%$ \\
\hline Mondal et al. (2011) [19] & $29.9 \%$ & $15.9 \%$ & $11.1 \%$ \\
\hline Amod et al (2017) [17] & $12.58 \%$ & $2.09 \%$ & $1.39 \%$ \\
\hline Yasmin et al. (2008) [20] & $24 \%$ & $18 \%$ & - \\
\hline Present study & $38 \%$ & $22 \%$ & $20 \%$ \\
\hline
\end{tabular}

\section{Conclusion}

From the present study we conclude that Benign ovarian tumors are more common than the Malignant tumors. The most common age group for occurrence of ovarian tumors is 20-39 years. Among benign tumors, serous cystadenoma is common, which is frequently bilateral. While second most common is Mature cystic teratoma. Malignant neoplasms of ovary are rare as compared to Benign neoplasms but require a specific attention during diagnosis on both clinical and pathological basis in order to save the patient's life.

\section{Source of Funding: Self.}

Declaration of Conflicts of Interest: The authors declare that they have no conflicts of interest.

\section{References}

[1] Sikdar K, Kumar P, Roychowdhary NN. A study of ovarian malignancy: A review of 149 cases. J Obstet Gynaecol India 1981;30:478-80.

[2] Young RH. The ovary. In: Sternberg S. diagnostic Surgical Pathology. 17th Ed. New York: Raven Press; 1994. p. 2195.

[3] 3. Novak. Gynacologic and obstetric pathology with clinical and endocrine relation. 8th ed. W.B.: saunders company; 1979

[4] Tortolero-Luna G, Mitchell MF. The epidemiology of ovarian cancer. J Cell Biochem Suppl 1995; 23:2007. [PUBMED]

[5] Merino MJ, Jaffe G. Age contrast in ovarian pathology. Cancer 1993; 712 Suppl:537 44.

[6] Modi D, Rathod GB, Delwadia KN, Goswami HM. Histopathological pattern of neoplastic ovarian lesions. IAIM. 2016;3(1):51-7.
[7] Padubidri VG, Daftary SN. Howkins \& Bourne.Pattern of ovarian lesions, Shaw's Textbook of Gynecology, 16th edition. Elsevier, 2014, 429-36

[8] Vinay Kumar, Abul K Abbas, Jon C. Aster pathology of female genital tract, Robbins and Cotran Pathological Basis of Disease, 9th edition (II). Elsevier 2015;(22):1023.

[9] Ameena A, Saeed S, Ayesha I, Abdullah A, Furrakh K, Nazeefa A. The relative frequency and histopathological pattern of ovarian masses. Biomedica. 2012:98-102.ssss

[10] Barber HR. Embryology of the gonad with reference to special tumours of the ovary and testis. Journal of pediatric surgery. 1988:967-72.

[11] Modugno F. Ovarian cancer and polymorphisms in the androgen and progesterone receptor genes. Am J Epidemol. 2004;159(4):319-35. Available from: https://doi. org/10.1093/aje/kwh046

[12] Prakash A, Chinthakindi S, Duraiswami R, Indira V. Histopathological study of ovarian lesions in a tertiary care center in Hyderabad, India: a retrospective five year study Int J Adv Med 2017;4(3):745-49.

[13] Maru AM, Menapara CB. Histopathological study of Non-neoplastic \& Neoplastic ovarian lesions in a tertiary care hospital in Gujarat, India. Trop J Path Micro 2019;5(2):63-68.doi:10.17511/jopm.2019.i02.03

[14] Misra RK, Sharma SP, Gupta U, Gaur R, Misra SD. Pattern of ovarian neoplasms in eastern UP. J Obstet Gynecol 1990;41(2):242-6

[15] Couto F, Nadkarni NS, Rebello MJ. Ovarian tumors in Goa. A Clinicopathological study. J Obstet Gynecol of India 1993;43(3):408-12.

[16] Pilli GS, Sunitha KP, Dhaded AV, Yenni VV. Ovarian tumors - a study of 282 cases. J Indian Med Associ 2002;100(7):420-4.

[17] Amod Sawant, Suresh Mahajan. histopathological study of ovarian lesions at a tertiary health care institute, MVP Journal of Medical Sciences 2017;4(1):26-29.

[18] Gupta N, Bisht D, Agarwal AK, Sharma VK. Retrospective an prospective study of ovarian tumours and tumour-like lesions. Indian J Pathol Microbiol 2007;50(3):525-7. PMid:17883123

[19] Mondal SK et al. Histologic pattern, bilaterality and clinical evaluation of 957 ovarian neoplasms: a 10 years study in a tertiary hospital of Eastern India. J Can Res Ther 2011;7:433-7.

[20] Yasmin S, Yasmin A, Asif M. Clinicohistological pattern of ovarian tumours in Peshawar region. J Ayub Med Coll Abbottabad 2008;20(4):11-3.

[21] Bhuvanesh U, Logambal A. Study of ovarian tumours. J Obstet Gynaecol India. 1978;28:271-77.

[22] Ramachandran G, Harilal KR, Chinnamma K, Thangavelu H. Ovarian neoplasms -A study of 903 cases. J Obstet Gynecol India 1972; 22:309-15.

[23] Modi D, Rathod GB, Delwadia KN, Goswami HM. Histopathological pattern of neoplastic ovarian lesions. IAIM 2016; 3(1):51-7. 